\title{
Kernel Biochemical Aspects in Stressed Wheat in Response to Glycine Betaine and Salicylic Acid
}

\author{
Heshmat Aldesuquy* \\ Department of Botany, Mansoura University, Egypt
}

Submission: May 16, 2017; Published: June 16, 2017

"Corresponding author: Heshmat Aldesuquy, Department of Faculty of Science, Mansoura University, Egypt, Email: heshmat-aldesuquy@hotmail.com

\begin{abstract}
A pot experiment was conducted to evaluate the positive effect of foliar application of glycine betaine $(10 \mathrm{~mm})$, grain presoaking in salicylic acid $(0.05 \mathrm{M})$ and their interaction on biochemical aspects of yielded grains of two droughted wheat (Triticum aestivum L.) cultivars (sensitive, Gemmieza 11 and tolerant, Sids-1). Water stress decreased grain biomass, carbohydrates, total protein, total phosphorus, ions content, amino and fatty acids in both wheat cultivars. The applied chemicals appeared to mitigate the negative effects of water stress on the biochemical aspects of yielded grains particularly the sensitive one. Water stress caused remarkable increase in all detected amino acids. In addition, application of GB, SA or their interaction induced additional increases in detected amino acids in kernels of the two wheat cultivars. The effect was more pronounced with GB+SA treatment. Furthermore, marked increase recorded in TSFA in response to water stress was accompanied with a noticeable reduction in TUFA in yielded grains of drought wheat cultivars. Sids 1 proved to be more tolerant than Gemmieza 11 where more increment in TSFA and more reduction in TUFA, MUFA as well as PUFA. SA and/or GB treatment induced marked increase in TSFA and noticeable reduction in TUFA in yielded grains of both stressed and unstressed wheat cultivars.
\end{abstract}

Keywords: Drought; Glycine betaine; Salicylic acid; Amino and fatty acids; Wheat

Abbreviations: GB: Glycine Betaine; SA: Salicylic Acid; WS: Water Stress; TSFA: Total Saturated Fatty Acids; TUFA: Total Unsaturated Fatty Acids

\section{Introduction}

Deficit irrigation provides a means of reducing water consumption while minimizing adverse effects on yield [1]. Furthermore, they found that severe soil water deficit (SWD) decreased grain yield of winter wheat, while slight SWD in the growth stage from spring green up to grain-filling did not reduce grain yield or water use efficiency.

Drought, being the most important environmental stress, severely impairs plant growth and development, limits plant production and the performance of crop plants, more than any other environmental factor [2]. Plant experiences, drought stress either when the water supply to roots becomes difficult or when the transpiration rate becomes very high. Available water resources for successful crop production have been decreasing in recent years. Furthermore, in view of various climatic change models scientists suggested that in many regions of world, crop losses due to increasing water shortage will further aggravate its impacts [3].

For instance, an accumulation of Glu has been reported in the wheat grains under salinity [4]. This accumulation of Glu could have been caused by both, the activation of biosynthesis from Glu and the inactivation of Glu degradation [5].
Numerous studies have demonstrated that the composition of fatty acids can be altered in response to drought, with the extent of those changes depending upon the plant species, organ or severity of the stress [6, 7]. Dornbos \& Mullen [8] reported that drought stress can increase stearic acid and decrease oleic acid. However, the increase or decrease depended on the severity of drought [9]. So far, few works have been done on the effect of environmental factors such as drought on fatty acid composition of wheat grains.

Glycine betaine (GB) is an amino acid derivative which is naturally synthesized in several plant species. However, many important crop species, like potato or tomato are unable to accumulate glycine betaine. Synthesis of glycine betaine is promoted by salt and drought stress as it functions as a compatible solute regulating the intracellular osmotic balance [10]. In addition, the positive effects of foliar spray of GB on yield and yield component in plants grown under water limited environment been reported in different crops such as rice [11] and common bean $[10,12,13]$.

Salicylic acid (SA) has been reported to cause a multitude of effects on the morphology and physiology of plants [14] and to 
induce a protective mechanism enhancing resistance to biotic and abiotic stresses [15]. Furthermore, Exogenous application of glycine betaine (GB) and salicylic acid (SA) has been found very effective in reducing the adverse effects of drought stress on sunflower plants [16].

The present work was designed to evaluate the possible role of GB, SA or their interaction in modifying stress imposed by drought on grain biochemical aspects of two droughty wheat cultivars.

\section{Material and Methods}

Two wheat cultivars (Triticum aestivum L.) Gemmieza11 (sensitive var.) and Sids-1 (tolerant var.), were used in this study. The variety Sids- 1 is known to be more drought tolerant than Gemmieza11.

\section{Experimental design}

Wheat grains of two winter wheat cultivars, (i.e. either sensitive or tolerant var.) were separately surface sterilized by soaking in $0.01 \% \mathrm{HgCl}_{2}$ for 3 minutes, followed by thoroughly rinsing in sterile water. The sterilized grains from each variety were divided into two sets $(\approx 500 \mathrm{~g}$ per set for each var.). Grains of the $1^{\text {st }}$ and $2^{\text {nd }}$ sets were separately soaked in distilled water or salicylic acid (0.05M), respectively. In 20 November 2005, grains of each set were planted in plastic pots (fifteen grains per pot; $25 \mathrm{~cm}$ width $X 30 \mathrm{~cm}$ height) filled with $6 \mathrm{~kg}$ mixture of soil (clay and sand $=2: 1 \mathrm{v} / \mathrm{v}$ ). The pots were kept in a greenhouse, and the plants were subjected to natural day/ night conditions (minimum/maximum air temperature and relative humidity were; $29.2 / 33.2^{\circ} \mathrm{C}$ and $63 / 68 \%$, respectively). Irrigation to field capacity was carried out when soil water content had fallen to $60 \%$ of its initial value. Twenty days after planting, the plants were thinned to five uniform seedlings per pot.

\section{Drought stress regimes}

On the day 65 (at the beginning of heading) after planting the pots of the $1^{\text {st }}$ set was allocated to four groups (20 pots per each group) as follow: control (cont.), water stress (WS), glycine betaine control (GB.), glycine betaine+water stress (GB+WS). The $2^{\text {nd }}$ set group was allocated as follow: salicylic acid control (SA), salicylic acid+water stress (SA+WS), control glycine betaine+salicylic acid $(\mathrm{GB}+\mathrm{SA})$ and glycine betaine+salicylic acid+water stress $(G B+S A+W S)$. For glycine betaine $(10 \mathrm{~mm})$ treatment, the plants were sprayed by glycine betaine $48 \mathrm{hrs}$ before starting the stress period and weekly during the stress period. Water deficit was imposed by withholding water at the reproductive stage for 30 days within two periods: on the day 65 from planting (heading stage) and the day 80 from planting (anthesis stage).

Each drought pot received $500 \mathrm{ml}$ water at the end of $1 \mathrm{st}$ stress period. At the end of stress periods, re-watering to the field capacity was carried out. The un-drought (control) plants were irrigated to the field capacity during the stress period, and all plants were left to grow until grain maturation under normal irrigation with tap water. At the bud stage, 20 days from planting, (i.e., tillering stage) and before heading (i.e., at ear emergence) the plants received $35 \mathrm{~kg} \mathrm{~N}$ ha- 1 as urea and $35 \mathrm{~kg} \mathrm{P}$ ha- 1 as potassium dihydrogen phosphate as fertilizers. At harvest date (after complete maturation of grains), samples were taken from different treatments for the following estimation (triplicates for biochemical analyses and ten samples for grains biomass).

\section{Determination of carbohydrates}

Total soluble sugars and sucrose were extracted and determined using modifications of the procedures of Riazi et al. [17]. Glucose contents were estimated using the 0 -toluidine procedure of Riazi et al. [17]. Polysaccharides were determined by the method of Thayermanavan \& Sadasivam [18]. Determination of protein. The protein content of fresh plant materials was determined calorimetrically as described by Lowry et al. [19].

\section{Determination of amino acids}

All free amino acids were extracted with ethanol and then hydrolyzed with $6 \mathrm{~N} \mathrm{HCl}$ for $24 \mathrm{hrs}$ according to the Sempio \& Raggi [20]. The extracted amino acids were then measured using a LKB alpha high performance amino acid analyzer (LKB Biochrom. LKD England). Retention time and area were determined using Hewlett Packard 3390 recording integrator. Concentration of each amino acid GM/16GM nitrogen was calculated by special designed program.

\section{Fatty Acids Analysis}

\section{Lipid extraction}

The method of lipids extraction was adopted by Neumann (1995). Methylation of fatty acids for gas-liquid chromatography analysis. The method used in this investigation was essentially that adopted by Sink et al. (1964). The fatty acids were converted to methyl esters by refluxing for 2 hours in a conical flask containing $0.5 \mathrm{~g}$ of oil (crude liquid extract the wheat flag leaf), $25 \mathrm{ml}$ methyl alcohol and $0.5 \mathrm{ml}$ concentrated $\mathrm{H}_{2} \mathrm{SO}_{4}$. The mixture was cooled and extracted with diethyl ether several times using a separating funnel. The combined ether extracts were thoroughly washed several times with distilled water till the washing gave no acidic reaction with Litmus paper and become free from any traces of sulphuric acid. Fatty acids extract were dried using anhydrous sodium sulphate, filtered and the ether was removed by distillation on a warm water bath under vacuum in $\mathrm{CO}_{2}$ gas atmosphere, till the last traces of solvent were removed. The sample was cooled in a desiccator and fatty acids methyl ester was taken for GLC injection.

\section{Gas Liquid Chromatography (GLC)}

One $\mu \mathrm{L}$ of fatty acid methyl ester was injected into internal diameter column packed with $20 \%$ diethylene glycol succinate (DEGS) on chromorb 60-80 mesh by using Shimadzu (model: Shimadzu GC/MS- Qp5050A).

\section{Determination of some mineral ions}

The extracts of the experimental plants were analyzed for the cations: $\mathrm{Na}^{+}, \mathrm{Ca}^{+2}$ and $\mathrm{Mg}^{+2}$ measured by flam emission 
spectrophotometery [21] whereas anions Cl-chlorides were determined by the $\mathrm{AgNO}_{3}$ titration method as described by Hansen \& Munns [22].

\section{Determination of phosphorus}

The procedure adopted for extraction of the different phosphorus compounds were essentially those described by Barker \& Mapson [23] and determined by method described by Humphries [24].

\section{Statistical analysis}

The main effect of factors (watering regime, used chemicals, growth stages and wheat cultivar) and interaction (watering regime, both used chemicals, growth stages and wheat type) were evaluated by general linear model (two way ANOVA) using SPSS program.

\section{Results and Discussion}

Generally, the grain fresh and dry masses, polysaccharides, total carbohydrates and total protein are decreased in response to water stress in both two wheat cultivars (Table 1 \& 2). These results showed that, water withholding occurred during grain filling particularly at the $2^{\text {nd }}$ stress period (at an thesis) might cause the following events: 1-led to an increase in ABA levels in flag leaves which in turn induced stomata closure and consequently decreased photosynthetic activity in flag leaves (the main source of photo-assimilates towards developing grains). This effect may result in a decrease in the grain biomass, 2-water stress decreased the leaf area by inducing leaf rolling particularly in susceptible cultivar and this may decrease the dry matter production that translocation towards developing grains, 3 -water stress may stimulate the early senescence in wheat leaves particularly in susceptible cultivar which also affected the translocation of the photo-assimilates from leaves (particularly flag leaf) which represents the main export source towards the main import sink (developing grain) $[12,13]$. Bearing in mind the conclusion of Egeli et al. [25] that the accumulation of dry matter by grains requires the production of assimilates in the leaves, their translocation to the fruit, movement into the storage organs of seed, and the synthesis of materials to be stored.

Table 1: Effect of glycine betaine, salicylic acid and their interaction on grain biomass and carbohydrate content of yielded grains of droughted wheat cultivars.

\begin{tabular}{|c|c|c|c|c|c|c|c|c|}
\hline \multirow[t]{2}{*}{$\begin{array}{l}\text { Wheat } \\
\text { Cultivar }\end{array}$} & \multirow{2}{*}{$\begin{array}{l}\text { Parameter } \\
\text { Treatment }\end{array}$} & \multicolumn{2}{|c|}{ Grain Biomass (Mg Grain-1) } & \multicolumn{5}{|c|}{ Carbohydrates Content (Mg G1- D Wt) } \\
\hline & & $\begin{array}{c}\text { Grain Fresh } \\
\text { Mass }\end{array}$ & $\begin{array}{l}\text { Grain Dry } \\
\text { Mass }\end{array}$ & Glucose & Sucrose & $\begin{array}{l}\text { Total Soluble } \\
\text { Sugar }\end{array}$ & Polysa-Charides & Total Carbohy-Drates \\
\hline \multirow{9}{*}{ Sensitive } & Cont & 53.2 & 47 & 2.77 & 13.81 & 18.61 & 724.7 & 741.1 \\
\hline & WS & 44.2 & 40.3 & 3.48 & 18.24 & 25.76 & 530.2 & 552 \\
\hline & GB & 55 & 50.5 & 2.94 & 14.4 & 20.17 & 733.4 & 750.1 \\
\hline & $\mathrm{GB}+\mathrm{WS}$ & 53.8 & 47.3 & 3.95 & 20.93 & 27.12 & 676.7 & 700.6 \\
\hline & SA & 55.9 & 50.1 & 3.02 & 14.77 & 20.93 & 752.5 & 769.9 \\
\hline & $\mathrm{SA}+\mathrm{WS}$ & 50.7 & 47.8 & 3.91 & 22.13 & 29.81 & 686.2 & 711.6 \\
\hline & $\mathrm{GB}+\mathrm{SA}$ & 59.2 & 54.4 & 3.15 & 14.99 & 21.37 & 759.6 & 777.7 \\
\hline & $\mathrm{GB}+\mathrm{SA}+\mathrm{WS}$ & 56.5 & 52.7 & 4.49 & 22.53 & 31.93 & 702.1 & 729.5 \\
\hline & LSD 0.05 & 3.2 & 2.25 & 0.35 & 3.2 & 1.7 & 7.6 & 9.6 \\
\hline \multirow{9}{*}{ Tolarent } & Cont. & 53.5 & 47.7 & 2.4 & 11.31 & 16.4 & 750.3 & 768.9 \\
\hline & WS & 45.6 & 41.6 & 2.94 & 15.52 & 21.83 & 645.1 & 670.9 \\
\hline & GB & 56 & 51.7 & 2.58 & 11.76 & 16.7 & 769.2 & 789.3 \\
\hline & $\mathrm{GB}+\mathrm{WS}$ & 53.9 & 50.3 & 3.17 & 17.49 & 23.88 & 716.5 & 743.7 \\
\hline & SA & 58.3 & 53.1 & 2.77 & 12.48 & 17.43 & 763.5 & 784.4 \\
\hline & $\mathrm{SA}+\mathrm{WS}$ & 56.5 & 51.3 & 3.27 & 18.13 & 25.44 & 704.5 & 734.3 \\
\hline & $\mathrm{GB}+\mathrm{SA}$ & 64.6 & 60.9 & 2.86 & 12.76 & 18.15 & 783.6 & 805 \\
\hline & $\mathrm{GB}+\mathrm{SA}+\mathrm{WS}$ & 61.7 & 58.3 & 3.3 & 19.86 & 27.4 & 641.4 & 673.3 \\
\hline & LSD at $P \leq 0.05$ & 3 & 3 & 0.22 & 2.8 & 1.5 & 11.81 & 13.02 \\
\hline
\end{tabular}

The above-mentioned results are in accord with those obtained by Sankar et al. [26]. Water deficits decreased both individual grain weight and grain yield. Nitrogen content per grain was quite high and similar for all treatments, and nitrogen percentage increased when stress was severe enough to reduce starch accumulation. This confirms that starch accumulation is more sensitive to post-anthesis stress than nitrogen accumulation.
Application of GB, SA or their interaction appeared to mitigate the deleterious effects of water stress on grain biomass of the two wheat cultivars. The repairing effect of SA may be attributed to the fact that SA reduces the rate of transpiration from leaves [27], which could possibly lead to the accumulation of excessive water, thus resulting consequently in an increase in grain fresh mass. Furthermore, GB application may act in the same manner as $\mathrm{SA}$ in inducing drastic reduction in the rate of transpiration. 
The results obtained from diurnal changes in transpiration rate make this postulation decisive [13].

The results indicated that, soluble sugars are accumulated in response to water stress in both wheat cultivars. On the other hand, water stress induced massive decrease in polysaccharides content in yielded grains of both wheat cultivars. This may probably due to the fact that water stress stimulates the degradation of polysaccharides and at the same time increases the dark respiration during which a part of soluble sugars was consumed as a respiratory substrate. The other part of soluble sugars may explain the massive increase in total soluble sugars occurred within the developing grains as a result of water stress. From another point of view, water stress decreased the pigment concentration in wheat leaves [12] which results in inhibition of photosynthetic activity, in turn it leads to less accumulation of carbohydrates in mature leaves and consequently may decrease the rate of transport of carbohydrates from leaves to the developing grains, where there is a good relationship between source (leaves) and sink (grain) in cereal plants. Furthermore, the noticed decrease in polysaccharides of wheat grains as a result of water stress could be explained on the fact that, water stress impaired the utilization of carbohydrates during the vegetative growth and reduced the area of conductive canals (mainly phloem and xylem), so reduction in the translocation of the assimilates toward the developed grains might have occurred [13]. In accord with these results, several physiological studies suggested that under stress conditions nonstructural carbohydrates (sucrose, hexoses, and sugar alcohols) accumulate although to varying degree in different plant species. A strong correlation between sugar accumulations and osmotic stress tolerance has been widely reported, including transgenic experiments [28].

Phosphorus content (organic, inorganic and total) in wheat grains increased due to water stress application. El-Tayeb [29] recorded that phosphorus increased in barley plants due to salinity. In addition, application of GB, SA or their interaction caused additional accumulation in phosphorus content in both wheat cultivars yielded grains (Table 2). Water stress stimulates the accumulation of both calcium and sodium content but decreased the magnesium and chloride content in the yielded grains of the two wheat cultivars. This increase in calcium and sodium levels may result from transportation of these elements from root to shoot through the transpiration stream to the developing grains. In addition, application of GB, SA or interaction seemed to induce additional increase in ionic content (calcium, sodium, magnesium and chloride) of the developed grains (Table 2).

Table 2: Effect of glycine betaine, salicylic acid and their interaction on total protein, phosphorous and ionic content of yielded grains of droughted wheat cultivars.

\begin{tabular}{|c|c|c|c|c|c|c|c|c|c|}
\hline \multirow{2}{*}{$\begin{array}{l}\text { Wheat } \\
\text { Cultivar }\end{array}$} & \multirow{2}{*}{$\begin{array}{l}\text { Parameter } \\
\text { Treatment }\end{array}$} & \multirow{2}{*}{$\begin{array}{l}\text { Total Protien } \\
\text { (Mg G-1) }\end{array}$} & \multicolumn{7}{|c|}{ Phosphorus Content } \\
\hline & & & $\begin{array}{l}\text { Inorganic } \\
\text { Phosph. }\end{array}$ & $\begin{array}{l}\text { Organic } \\
\text { Phosph. }\end{array}$ & $\begin{array}{c}\text { Total } \\
\text { Phosph. }\end{array}$ & $\mathrm{Ca}^{+2}$ & $\mathbf{M g}^{+2}$ & $\mathrm{Cl}^{-}$ & $\mathrm{Na}^{+1}$ \\
\hline \multirow{9}{*}{ Sensitive } & Cont & 98.9 & 0.05 & 0.45 & 0.5 & 1.54 & 11.2 & 1.25 & 1.8 \\
\hline & WS & 75.6 & 0.07 & 0.48 & 0.55 & 1.79 & 9.1 & 0.5 & 2.1 \\
\hline & GB & 120.5 & 0.06 & 0.5 & 0.56 & 1.88 & 11.3 & 1.5 & 1.9 \\
\hline & $\mathrm{GB}+\mathrm{WS}$ & 100.5 & 0.1 & 0.61 & 0.71 & 1.85 & 10.4 & 1 & 2.2 \\
\hline & SA & 117.1 & 0.07 & 0.51 & 0.59 & 1.72 & 11.9 & 1.75 & 1.95 \\
\hline & $\mathrm{SA}+\mathrm{WS}$ & 101.6 & 0.11 & 0.66 & 0.77 & 1.89 & 10.2 & 1.25 & 2.3 \\
\hline & $\mathrm{GB}+\mathrm{SA}$ & 128.7 & 0.08 & 0.59 & 0.67 & 1.75 & 12.1 & 1.85 & 1.98 \\
\hline & $\mathrm{GB}+\mathrm{SA}+\mathrm{WS}$ & 105.3 & 0.12 & 0.68 & 0.8 & 1.96 & 10.5 & 1.25 & 2.4 \\
\hline & LSD 0.05 & 2.73 & 0.01 & 0.02 & 0.01 & 0.35 & 1.2 & 0.35 & 0.17 \\
\hline \multirow{9}{*}{ Tolerant } & Cont. & 102.3 & 0.07 & 0.45 & 0.52 & 1.53 & 11.3 & 1.3 & 1.9 \\
\hline & WS & 94 & 0.11 & 0.47 & 0.58 & 1.78 & 10 & 0.75 & 2.1 \\
\hline & GB & 128.4 & 0.12 & 0.47 & 0.59 & 1.69 & 11.4 & 1.75 & 1.98 \\
\hline & $\mathrm{GB}+\mathrm{WS}$ & 108.9 & 0.15 & 0.58 & 0.74 & 1.95 & 10.5 & 0.95 & 2.25 \\
\hline & SA & 125.9 & 0.13 & 0.49 & 0.63 & 1.68 & 11.7 & 1.9 & 1.97 \\
\hline & $\mathrm{SA}+\mathrm{WS}$ & 106.3 & 0.17 & 0.62 & 0.79 & 1.9 & 10.7 & 1 & 2.24 \\
\hline & $\mathrm{GB}+\mathrm{SA}$ & 135.5 & 0.17 & 0.53 & 0.69 & 1.76 & 12.3 & 1.95 & 1.99 \\
\hline & $\mathrm{GB}+\mathrm{SA}+\mathrm{WS}$ & 114 & 0.27 & 0.57 & 0.85 & 2.14 & 11 & 1 & 2.26 \\
\hline & $\begin{array}{l}\text { LSD at } \\
\mathrm{p} \leq 0.05\end{array}$ & 3.64 & 0.01 & 0.02 & 0.02 & 0.16 & 0.91 & 0.36 & 0.31 \\
\hline
\end{tabular}

Under water stress, protein content of the developed grains was significantly decreased in both wheat cultivars. The decrease in protein contents in yielded grains was more pronounced in the sensitive cultivar than the tolerant one under drought, this may probably be due to less transport of protein from source (flag leaf) to the sink (grain). In support, water stress induced 
remarkable decrease in soluble protein in flag leaf at heading and anthesis[12]. The decrease in protein content in yielded grains as a result of drought stress was alleviated by the application of GB, SA or their interaction. In connection with these results, Mäetak el al. 2000 found increased protein in tomato plants under drought or salinity by means of foliar-applied GB. In addition, similar results are obtained by El-Tayeb [29].

In this investigation, water stress induced a massive increase in total amino acids detected in the harvested grains of the two

Table 3: Effec t of glycine betaine, salicylic acid and their interaction on amino acids content $(\mathrm{mg} / 100 \mathrm{~g} \mathrm{f} \mathrm{wt})$ in the developed grains of sensitive wheat cultivar.

\begin{tabular}{|c|c|c|c|c|c|c|c|c|c|}
\hline $\begin{array}{l}\text { Treatment } \\
\text { Parameter }\end{array}$ & Cont & ws & GB & $G B+W S$ & SA & $\mathrm{SA}+\mathrm{WS}$ & $\mathrm{GB}+\mathrm{SA}$ & GB & LSD at $\mathrm{P} \leq 0.05$ \\
\hline Glutamic & 8.25 & 8.95 & 8.62 & 10.17 & 8.43 & 9.54 & 8.87 & 10.66 & 0.32 \\
\hline Aspartic & 6.12 & 7.71 & 6.94 & 8.51 & 6.47 & 8.24 & 6.66 & 8.75 & 1.32 \\
\hline Leucine & 5.11 & 5.64 & 5.46 & 6.7 & 5.31 & 6.32 & 5.44 & 6.57 & 0.35 \\
\hline Tyrosine & 3.26 & 5.15 & 4.88 & 6.44 & 4.23 & 5.83 & 4.65 & 6.21 & 1.23 \\
\hline Alanine & 2.64 & 3.32 & 3.17 & 5.11 & 3.01 & 4.26 & 3.72 & 6.25 & 1.12 \\
\hline Isoleucine & 2.55 & 3.15 & 2.95 & 4.01 & 2.53 & 3.42 & 2.81 & 3.73 & 0.63 \\
\hline Threonine & 2.12 & 3.13 & 3.65 & 4.21 & 2.35 & 3.86 & 3.41 & 4.15 & 0.75 \\
\hline Serine & 2.02 & 2.77 & 2.56 & 3.72 & 2.11 & 3.05 & 2.48 & 3.25 & 1.06 \\
\hline Proline & 1.85 & 2.69 & 2.13 & 3.19 & 1.96 & 2.54 & 2.25 & 3.38 & 0.68 \\
\hline Arginine & 1.36 & 2.06 & 1.78 & 2.65 & 1.53 & 2.14 & 1.96 & 2.72 & 0.58 \\
\hline Valine & 1.12 & 2.03 & 2.15 & 2.41 & 1.65 & 1.87 & 1.77 & 2.23 & 0.45 \\
\hline Glycine & 0.79 & 1.27 & 1.11 & 1.45 & 1.05 & 1.34 & 1.25 & 1.88 & 0.47 \\
\hline Histidine & 0.72 & 0.97 & 0.83 & 1.05 & 0.76 & 1.04 & 0.86 & 1.12 & 0.17 \\
\hline Methionine & 0.65 & 0.73 & 0.69 & 0.86 & 0.67 & 0.77 & 0.71 & 0.89 & 0.06 \\
\hline $\begin{array}{l}\text { Pheynl } \\
\text { alanine }\end{array}$ & 0.63 & 0.89 & 0.76 & 1.16 & 0.68 & 0.92 & 0.72 & 1.11 & 0.19 \\
\hline Cysteine & 0.53 & 0.62 & 0.57 & 0.78 & 0.55 & 0.66 & 0.55 & 0.73 & 0.04 \\
\hline Iysine & 0.47 & 0.68 & 0.52 & 0.76 & 0.49 & 0.72 & 0.65 & 0.95 & 0.13 \\
\hline Total FAA & 38.56 & 49.58 & 46.92 & 60.48 & 42.07 & 54.23 & 46.84 & 61.79 & 9.19 \\
\hline Ammonia & 1.26 & 1.58 & 1.44 & 1.76 & 1.35 & 1.64 & 1.51 & 1.82 & 0.22 \\
\hline
\end{tabular}

Table 4: Effect of glycine betaine, salicylic acid and their interaction on amino acids content $(\mathrm{mg} / 100 \mathrm{~g} \mathrm{wt}$ ) in the developed grains of tolerant wheat cultivar.

\begin{tabular}{|c|c|c|c|c|c|c|c|c|c|}
\hline $\begin{array}{c}\text { Treatment } \\
\text { Parameter }\end{array}$ & Cont & WS & GB & GB+WS & SA & SA+WS & GB+SA & GB +SA+WS & LSD at P $\mathbf{0 . 0 5}$ \\
\hline Glutamic & 7.16 & 8.46 & 7.54 & 9.16 & 7.38 & 8.75 & 7.78 & 9.48 & 0.84 \\
\hline Aspartic & 5.32 & 6.54 & 5.95 & 7.38 & 5.44 & 6.85 & 6.03 & 8.14 & 1.05 \\
\hline Leucine & 4.31 & 5.43 & 5.02 & 6.51 & 4.67 & 6.13 & 4.89 & 6.37 & 0.83 \\
\hline Tyrosine & 2.43 & 3.55 & 2.73 & 4.99 & 2.56 & 3.95 & 2.7 & 4.54 & 1.32 \\
\hline Alanine & 2.13 & 2.78 & 2.66 & 3.46 & 2.35 & 2.98 & 3.45 & 4.28 & 0.35 \\
\hline Isoleucine & 2.04 & 2.67 & 2.84 & 3.59 & 2.33 & 2.92 & 2.63 & 3.24 & 0.74 \\
\hline Threonine & 1.67 & 2.07 & 2.32 & 3.49 & 1.85 & 2.85 & 2.12 & 3.27 & 1.24 \\
\hline Proline & 1.58 & 2.24 & 1.75 & 3.03 & 1.64 & 2.73 & 1.89 & 3.45 & 0.58 \\
\hline Serine & 1.45 & 2.03 & 1.63 & 2.72 & 1.53 & 2.21 & 1.61 & 2.53 & 0.42 \\
\hline Valine & 0.86 & 1.47 & 1.19 & 1.86 & 0.93 & 1.62 & 1.11 & 1.68 & 0.46 \\
\hline Glycine & 0.66 & 0.98 & 0.87 & 1.23 & 0.72 & 1.11 & 0.95 & 1.39 & 0.21 \\
\hline
\end{tabular}

wheat cultivars (Table $3 \& 4$ ). This may result from the enhanced production of amino acids as a result of increased proteolytic activities which may occur in response to the changes in osmotic adjustment of their cellu-lar contents [30]. The accumulation of free amino acids under stress at all the growth stages indicates the possibility of their involvement in osmotic adjustment Yadav et al. 2005. The amino acid content has been shown to increase under drought conditions in Abelmoschus esculentus [26]. 


\section{Agricultural Research \& Technology: Open Access Journal}

\begin{tabular}{|c|c|c|c|c|c|c|c|c|c|}
\hline Histidine & 0.68 & 0.85 & 0.77 & 0.96 & 0.71 & 0.89 & 0.82 & 1.03 & 0.14 \\
\hline Arginine & 0.62 & 0.89 & 0.72 & 1.39 & 0.68 & 1.14 & 0.78 & 1.57 & 1.05 \\
\hline lysine & 0.52 & 0.76 & 0.63 & 0.89 & 0.59 & 0.84 & 0.69 & 0.98 & 0.18 \\
\hline Pheynl alanine & 0.47 & 0.68 & 0.54 & 0.87 & 0.49 & 0.75 & 0.52 & 0.84 & 0.12 \\
\hline Methionine & 0.45 & 0.49 & 0.47 & 0.53 & 0.46 & 0.51 & 0.47 & 0.55 & 0.03 \\
\hline Cysteine & 0.37 & 0.46 & 0.42 & 0.57 & 0.38 & 0.48 & 0.41 & 0.56 & 0.06 \\
\hline Total FAA & 32.36 & 41.9 & 37.64 & 52.07 & 34.35 & 46.23 & 38.45 & 53.36 & 9.57 \\
\hline Ammonia & 0.92 & 1.25 & 1.08 & 1.55 & 0.97 & 1.46 & 1.11 & 1.68 & 0.17 \\
\hline
\end{tabular}

The obtained results indicated that glutamic acid was the most abundant amino acid in the yielded grains of the control and treated plants. These results are in a good agreement with those obtained by Caputo \& Barneix [31]. They found that, the amino acid composition of phloem sap is different in different species, in barley, Glu accounts for approximately $50 \%$ of the total amino acids, while Asp accounts for roughly $20 \%$ and in wheat, Glu amounted to $30 \%$ of the total amino acids, and Asp to $20 \%$, with these proportions changing with plant age. Also, in spinach, Glu was the most abundant amino acid, accounting for 39.1\%, followed by Asp (14.7\%) and Glu (10.1\%) [32] and Glu was also the dominating amino acid in the phloem of Beta vulgaris L. [33]. For instance, an accumulation of Glu has been reported in the wheat grains under salinity [4]. This accumulation of Glu could have been caused by both, the activation of biosynthesis from Glu and the inactivation of Glu degradation [5].

Water stress induced an accumulation in proline concentration in harvested grains in both wheat cultivars. Increased proline in the grain of stressed wheat plants may help to overcome any further stress conditions. Proline accumulates under stressed conditions supplies energy for growth and survival and thereby helps the plant to tolerate stress [34]. Treatments with GB, SA or their interaction induced remarkable increases in amino acids detected in the harvested grains of both wheat cultivars. This was in agreement with El-Tayeb [35] with sunflower plants treated with SA under $\mathrm{Cu}$ - stress conditions. Also, Hussein et al. [36] studied the effect of salicylic acid and salinity on growth of maize plants. They found that all amino acid concentrations are lowered by salinity except for proline and glycine. All determinate amino acid concentrations (except methionine) are increased with the application of salicylic acid $(200 \mathrm{ppm})$. On the other hand, methionine was negatively responded which slightly lowered. These chemicals may reduce proline oxidase and resulted in proline accumulation which acts as an osmolyte as well as scavenger.

Variation in fatty acids composition is most likely caused by environmental factors, these include salt and drought stress (Tables 5-8). According to Mikami \& Murata [37] tolerance of plants to salt and drought is strongly dependent on the inheritance of fatty acids levels. Perusal of the data cleared that in response to water stress, the pattern of changes in total saturated fatty acids (TSFA) is vice versa to that in total unsaturated fatty acids (TUFA). As compared to control plants, the increment recorded in TSFA in response to water stress was accompanied with a noticeable reduction in TUFA in yielded grains of droughted wheat cultivars. As water stress resulted in a marked increase in the concentration of each saturated fatty acids, there was a simultaneous decrease in the concentration of each unsaturated fatty acids in yielded grains of droughted wheat cultivars. Moreover, a clear trend of induction in TSFA/ TUFA with water stress was observed. Comparing cultivars, Sids1 proved to be more tolerant than Gemmieza-11 where more increment in TSFA and more reduction in TUFA, MUFA as well as PUFA were observed in Sids-1. These results were in accord with those obtained by Taarit et al. [38] in Salvia officinalis leaves under water stress. Moreover, Xu and Beardall [39] stated that in a Dunaliella $s p$ with increasing water stress level, the proportion of TSFA increased while PUFA decreased.

In connection, Nam et al. [40] reported that withholding irrigation led to an increment in the levels of stearic acid, linoleic acid, linolenic acid. By contrast, the values for oleic acid and behenic acid were reduced by this water shortage in brown rice. Moreover, Javed et al. [41] stated that, Amongst saturated fatty acid (palmitic and stearic acid) in sunflower, palmitic acid concentration has been noted to be increases in less water availability and stearic acid concentration lowers under drought while, water stress lowers the level of oleic acid and raises the linoleic in Different Safflower varieties.

At the same time, the recorded decline in the amount of TUFA as a response of wheat plants to stress circumstances would be advantageous in terms of fatty acids reserve for growth. Moreover, the advantage of having saturated fatty acid is that the yield of ATP molecules during complete oxidation is higher than unsaturated fatty acids [42]. The data showed that drought decreased the degree of fatty acids unsaturation in yielded grains of both drought wheat cultivars with greater reduction in Sids-1 than Gemmieza 11. This fact could be considered as one of the aspect of wheat adaptation to drought stress since some plants could be protected against the oxidative effects of water stress through restructuring membranes with less polyunsaturated fatty acids as indicated by Francois \& Kleiman [43]. Also, this low unsaturation degree limited the membrane fluidity [43] and so restricted its permeability to $\mathrm{Na}+$ and $\mathrm{Cl}$ - ions especially in Sids1 as concluded from our results. Hence, Sids-1 proved to be more tolerant than Gemmieza-11. 
Table 5: Effect of salicylic acid, glycine betaine and their interaction on saturated fatty acids $\left(\mu \mathrm{g} \mathrm{g}^{-1} \mathrm{~d}\right.$ wt) of yielded grains of droughted sensitive wheat cultivar.

\begin{tabular}{|c|c|c|c|c|c|c|c|c|c|c|}
\hline Wheat Cultivar & \multicolumn{9}{|c|}{ Sensitive } & \multirow[b]{2}{*}{ LSD at $p \leq 0.05$} \\
\hline \multicolumn{2}{|c|}{ Treatment Parameter } & Cont & wS & SA & SA+WS & GB & GB+WS & SA+GB & $\mathrm{SA}+\mathrm{GB}+\mathrm{WS}$ & \\
\hline \multirow{10}{*}{$\begin{array}{l}\text { Saturated Fatty } \\
\quad(\mu \mathrm{g} g-1 \mathrm{dwt})\end{array}$} & Caprylic acid $\left(\mathrm{C}_{8}\right)$ & - & - & - & - & - & - & - & 11.2 & 0.49 \\
\hline & Capric acid $\left(\mathrm{C}_{10}\right)$ & - & - & - & - & - & - & - & 16.8 & 0.122 \\
\hline & Lauric acid $\left(\mathrm{C}_{12}\right)$ & - & 12.2 & - & 38.9 & - & 37.1 & 18.6 & 204.6 & 0.816 \\
\hline & Myristic acid $\left(\mathrm{C}_{14}\right)$ & 8.9 & 17.4 & 31.7 & 170.2 & 29.7 & 51.2 & 97.2 & 363 & 1.14 \\
\hline & $\begin{array}{c}\text { acid }\left(\mathrm{C}_{15}\right) \\
\text { Pentadecanoic }\end{array}$ & - & 21.7 & 10.7 & 236 & 7.1 & 36.6 & 17.3 & 307.4 & 1.06 \\
\hline & Palmitic acid $\left(\mathrm{C}_{16}\right)$ & 21.7 & 41.8 & 38.2 & 59.3 & 32.5 & 53.7 & 44.7 & 416.7 & 0.816 \\
\hline & Heptadecanoic $\left(\mathrm{C}_{17}\right)$ & - & 16.9 & - & - & - & - & 69.4 & 268.7 & 0.415 \\
\hline & Stearic acid $\left(\mathrm{C}_{18}\right)$ & - & - & - & 28.9 & - & - & - & 52.1 & 0.545 \\
\hline & Arachidic acid $\left(\mathrm{C}_{20}\right)$ & 70.2 & 111.3 & 90.8 & 178.8 & 81.2 & 138.5 & 109.4 & 337.2 & 1.08 \\
\hline & Behenic acid $\left(\mathrm{C}_{22}\right)$ & - & - & - & 7.4 & - & - & - & 41.2 & 0.612 \\
\hline \multicolumn{2}{|c|}{$\begin{array}{l}\text { Total saturated fatty acids (TSFA) ( } \mu \mathrm{g} \\
\left.\qquad \mathrm{g}^{-1} \mathrm{~d} \mathrm{wt}\right)\end{array}$} & 100.8 & 231.1 & 180.3 & 750.3 & 150.5 & 342.7 & 349.4 & 2427.5 & 5.83 \\
\hline
\end{tabular}

Table 6: Effect of salicylic acid, glycine betaine and their interaction on saturated fatty acids ( $\mu \mathrm{g} \mathrm{g}^{-1} \mathrm{~d}$ wt) of yielded grains of droughted tolerant wheat cultivar.

\begin{tabular}{|c|c|c|c|c|c|c|c|c|c|c|}
\hline Wheat Cultivar & \multicolumn{10}{|c|}{ Tolerant } \\
\hline \multicolumn{2}{|c|}{ Treatment Parameter } & Cont & wS & SA & SA+WS & GB & GB+WS & $\mathrm{SA}+\mathrm{GB}$ & $\mathrm{SA}+\mathrm{GB}+\mathrm{WS}$ & LSD at $\mathrm{P} \leq 0.05$ \\
\hline \multirow{11}{*}{$\begin{array}{l}\text { Saturated fatty } \\
\left(\mu \mathrm{g} \mathrm{g}^{-1} \mathrm{dwt}\right)\end{array}$} & Caprylic acid(C8) & - & - & - & 32.1 & - & 31.2 & - & 40.7 & 0.85 \\
\hline & Capric acid(C10) & - & 17.8 & - & 60.03 & - & 48.9 & 37.4 & 61.6 & 1.04 \\
\hline & Lauric acid(C12) & 12.1 & 53.5 & 17.5 & 113.2 & 14.6 & 101.3 & 118.9 & 168.5 & 0.878 \\
\hline & Tridecanoic acid (C13) & - & - & - & 38.9 & - & 28.7 & 26.1 & 51.8 & 0.855 \\
\hline & Myristic acid(C14) & 71.9 & 131.2 & 392.7 & 627.4 & 100.4 & 125.8 & 212.7 & 718.9 & 2.1 \\
\hline & acid (C15) Pentadecanoic & - & 20.4 & 28.2 & 36.9 & 22.9 & 34.7 & 27.1 & 40.9 & 0.85 \\
\hline & Palmitic acid (C16) & 128.7 & 153.8 & 214.5 & 216.2 & 191.3 & 200.2 & 289.2 & 323.7 & 1.03 \\
\hline & Heptadecanoic(C17) & - & 30.9 & 28.2 & 36.9 & 22.9 & 34.7 & 27.1 & 40.9 & 0.769 \\
\hline & Stearic acid(C18) & 48.2 & 53.8 & 73.1 & 113.5 & 54.2 & 97.3 & 110.7 & 130.1 & 1.19 \\
\hline & Arachidic acid(C20) & 7.9 & 20.1 & 14.1 & 32.3 & 11.1 & 28.2 & - & 42.7 & 1.17 \\
\hline & Behenic acid(C22) & - & - & - & - & - & - & - & 21.9 & 0.061 \\
\hline \multicolumn{2}{|c|}{$\begin{array}{l}\text { Total saturated fatty acids (TSFA) ( } \mu \mathrm{g} \text { g-1 } \\
\qquad \mathrm{d} \mathrm{wt})\end{array}$} & 268.8 & 481.5 & 768.3 & 1307.4 & 417.4 & 731 & 849 & 1641.7 & 5.09 \\
\hline
\end{tabular}

Table 7: Effect of salicylic acid, glycine betaine and their interaction on unsaturated fatty acids ( $\mu \mathrm{g} \mathrm{g}^{-1} \mathrm{~d}$ wt) of yielded grains of droughted sensitive wheat cultivar.

\begin{tabular}{|c|c|c|c|c|c|c|c|c|c|c|}
\hline Wheat Cultivar & \multicolumn{10}{|c|}{ Sensitive } \\
\hline \multicolumn{2}{|c|}{ Treatment Parameter } & Cont & WS & SA & SA+WS & GB & GB+WS & $\mathrm{SA}+\mathrm{GB}$ & $\mathrm{SA}+\mathrm{GB}+\mathrm{WS}$ & $\begin{array}{c}\text { LSD at } P \leq \\
0.05\end{array}$ \\
\hline \multirow{3}{*}{ Fatty D $1 \mathrm{Wt}$} & $\begin{array}{l}\text { Palmitoleic acid } \\
\qquad \text { (C16:1) }\end{array}$ & - & - & 10.1 & - & 12.8 & - & 8.1 & - & 0.788 \\
\hline & Oleic acid (C18:1) & 172.9 & 108.2 & 117.3 & 91.2 & 167.1 & 96.8 & 101.3 & 82.4 & 1.14 \\
\hline & $\begin{array}{l}\text { Linoleic acid } \\
\text { (C18:2) (PUFA) }\end{array}$ & 83.1 & 73.4 & 72.8 & 63.1 & 79.7 & 69.4 & 68.1 & 60.5 & 1.15 \\
\hline \multicolumn{2}{|c|}{$\begin{array}{l}\text { Mono-unsaturated fatty acids (MUFA) }\left(\mu \mathrm{g} \mathrm{g}^{-1}\right. \\
\text { dwt) }\end{array}$} & 172.9 & 108.2 & 127.4 & 91.2 & 179.9 & 96.8 & 109.4 & 82.4 & 1.73 \\
\hline \multicolumn{2}{|c|}{$\begin{array}{l}\text { Total unsaturated fatty acids (TUFA) }\left(\mu \mathrm{g} \mathrm{g}^{-1}\right. \\
\text { dwt) }\end{array}$} & 255.6 & 181.6 & 200.2 & 154.3 & 259.6 & 166.2 & 177.5 & 142.9 & 2.59 \\
\hline \multicolumn{2}{|c|}{ TSFA / TUFA ratio } & 0.394 & 1.27 & 0.902 & 4.86 & 0.58 & 2.06 & 1.69 & 16.99 & 0.033 \\
\hline
\end{tabular}


Table 8: Effect of salicylic acid, glycine betaine and their interaction on unsaturated fatty acids ( $\mu \mathrm{g} \mathrm{g-1} d$ wt) of yielded grains of droughted tolerant wheat cultivar.

\begin{tabular}{|c|c|c|c|c|c|c|c|c|c|c|}
\hline Wheat cultivar & \multicolumn{10}{|c|}{ Tolerant } \\
\hline Treatment & & & & & & & & & & \\
\hline Parameter & Cont & WS & SA & $\mathrm{SA}+\mathrm{WS}$ & GB & $\begin{array}{l}\text { GB+ } \\
\text { ws }\end{array}$ & $\mathrm{SA}+\mathrm{GB}$ & $\begin{array}{l}\text { SA+ } \\
\text { GB+ }\end{array}$ & $\begin{array}{c}\text { SA+ GB+ } \\
\text { wS }\end{array}$ & $\begin{array}{l}\text { LSD at } \\
p \leq 0.05\end{array}$ \\
\hline \multirow{3}{*}{$\begin{array}{l}\text { Unsaturated } \\
\text { fatty acids }(\mu \mathrm{g} \\
\mathrm{g}-1 \mathrm{~d} w \mathrm{t})\end{array}$} & $\begin{array}{l}\text { Palmitoleic } \\
\text { acid (C16:1) }\end{array}$ & 64.8 & 10.4 & 58.1 & 8.8 & 61.7 & 9.9 & 41.5 & 7.4 & 0.857 \\
\hline & $\begin{array}{l}\text { Oleic acid } \\
\text { (C18:1) }\end{array}$ & 85.1 & 19.4 & 82.9 & 12.2 & 84.47 & 14.6 & 80.3 & 11.3 & 1.15 \\
\hline & $\begin{array}{c}\text { Linoleic } \\
\text { acid (C18:2) } \\
\text { (PUFA) }\end{array}$ & 68.7 & 8.8 & 63.2 & 5.9 & 65.4 & 6.8 & 61.2 & 4.5 & 0.880 \\
\hline $\begin{array}{c}\text { Mono- } \\
\text { unsaturated } \\
\text { fatty acids } \\
\text { (MUFA) ( } \mu \mathrm{gg} \text {-1 } \\
\text { d wt) }\end{array}$ & 149.9 & 29.8 & 141 & 21 & 146.17 & 24.5 & 121.8 & 18.7 & 1.53 & \\
\hline $\begin{array}{c}\text { Total } \\
\text { unsaturated } \\
\text { fatty acids } \\
\text { (TUFA) ( } \mu \mathrm{g} \text { g-1 } \\
\text { d wt) }\end{array}$ & 218.6 & 38.6 & 204.2 & 26.9 & 211.57 & 31.3 & 183 & 23.2 & 1.66 & \\
\hline $\begin{array}{l}\text { TSFA / TUFA } \\
\text { ratio }\end{array}$ & 1.23 & 12.47 & 3.76 & 48.65 & 1.97 & 23.36 & 4.64 & 70.82 & 1.88 & \\
\hline
\end{tabular}

The relative compositional changes in fatty acids induced by drought resulted in increased saturated/unsaturated ratio particularly in tolerant cultivar. Similar increment in this ratio has been reported by many investigators $[44,45]$ in different plant species in response to drought. Stressful environmental conditions not only lower the oil content it also alters the fatty acid composition [46]. Drought modified fatty acids composition and ultimately the food quality and it is considered to be very important in stress tolerance of plants [47]. Moreover extent of un saturation of fatty acids is correlated with potential of photosynthetic machinery to tolerate stress. Generally abiotic stress induces inactivation of PSII and PSI [48] and un saturation of fatty acids in membrane lipids shelter PSII and PSI as one of effective protective strategy. Where it affects dually; alleviating the damage to PSI and PSII and improving the healing of injury $[49,50]$. Fatty acid composition is generally affected by genotype (Knowles, 1988) and environmental conditions, particularly the level of unsaturation. Water stress causes a rise in oleic acid [51].

Salicylic acid and/or GB treatment induced a noticeable increase in TSFA and TSFA/ TUFA ratio as well as a noticeable reduction in TUFA in yielded grains of both stressed and unstressed wheat cultivars. Moreover, our results showed the appearance of new fatty acid (caprylic acid) in droughted wheat grains in response to SA and GB of both wheat cultivars and in droughted tolerant wheat cultivar treated with SA or GB alone. Also, the appearance of capric acid in droughted wheat grains in response to SA and GB of both wheat cultivars and in droughted tolerant wheat cultivar untreated or treated with SA or GB alone.
The disappearance of lauric acid in control sensitive wheat cultivar untreated or treated with SA or GB alone. Moreover, the disappearance of tridecanoic acid in control of both wheat cultivars and in droughted tolerant wheat cultivar untreated or treated with SA alone. In addition, results cleared the disappearance of pentadecanoic acid in yielded grains of control of both wheat cultivars and the disappearance of heptadecanoic acid in cont and water-stressed tolerant wheat cultivar treated with SA or GB alone.

Water-stress induced marked changes in fatty acids composition in yielded grains of both droughted wheat cultivars. Perusal of data cleared that drought increased TSFA concentration and decreased TUFA, MUFA as well as PUFA concentrations in yielded grains of both droughted wheat cultivars. By comparing the two cultivars, Gemmieza-11 showed more increment in TSFA and more reduction in TUFA, MUFA and PUFA. These results were in accord with those obtained by Taarit et al. [34] in Salvia officinalis leaves under water stress. Moreover, $\mathrm{Xu}$ and Beardall [39] stated that in a Dunaliella $s p$ with increasing water stress level, the proportion of TSFA increased while PUFA decreased.

At the same time, the recorded decline in the amount of TUFA as a response of wheat plants to stress circumstances would be advantageous in terms of fatty acids reserve for growth. Moreover, the advantage of having saturated fatty acid is that the yield of ATP molecules during complete oxidation is higher than unsaturated fatty acids [42]. The data showed that drought decreased the degree of fatty acids unsaturation in yielded grains of both droughted wheat cultivars with greater reduction 
in Gemmieza-11than Sids-1. This fact could be considered as one of the aspect of wheat adaptation to drought stress since some plants could be protected against the oxidative effects of water stress through restructuring membranes with less polyunsaturated fatty acids as indicated by Francois and Kleiman [43]. Also, this low unsaturation degree limited the membrane fluidity [44] and so restricted its permeability to $\mathrm{Na}+$ and $\mathrm{Cl}$ - ions especially in as concluded from our results.

Note, the disappearance of lauric acid in control sensitive wheat cultivar untreated or treated with SA or GB alone. Moreover, the disappearance of tridecanoic acid in control of both wheat cultivars treated with tre alone and in droughted tolerant wheat cultivar untreated or treated with SA alone. In addition, Our results cleared the disappearance of pentadecanoic acid in yielded grains of control of both wheat cultivars and the disappearance of heptadecanoic acid in cont and water-stressed tolerant wheat cultivar treated with SA or GB alone and finally the appearance of stearic acid and behenic acid in yielded grains of droughted sensitive wheat cultivar treated with SA alone or SA and GB and the appearance of behenic acid in yielded grains of droughted tolerant wheat cultivar treated with SA and GB $[52,53]$.

The most surprising results of the present study was that the interaction of SA and GB under water stress induced the appearance of caprylic acid and capric acid in yielded grains of sensitive wheat cultivars, while interaction of SA and GB under water stress induced the appearance of behenic acid in yielded grains of tolerant wheat cultivar. It was concluded application of GB, SA or their interaction induced additional increases in detected amino acids in kernels of the two wheat cultivars. The effect was more pronounced with GB+SA treatment. Furthermore, marked increase recorded in TSFA in response to water stress was accompanied with a noticeable reduction in TUFA in yielded grains of droughted wheat cultivars. Comparing cultivars, Sids- 1 proved to be more tolerant than Gemmieza11 where more increment in TSFA and more reduction in TUFA, MUFA as well as PUFA.

\section{References}

1. Zhang X, Zang R, Li C (2004) Population differences in physiological and morphological adaptations of Populus davidiana seedlings in response to progressive drought stress. Plant Sci 66: 791-797.

2. Shao HB, Liang ZS, Shao MA (2005) Changes of some physiological and biochemical indices for soil water deficits among 10 wheat genotypes at seedling stage. Colloids Surf B Biointerfaces 41: 107-113.

3. Anjum S, Xie XY, Wang LC, Saleem MF, Man C, et al. (2011) Morphological, physiological and biochemical responses of plants to drought stress. African Journal of Agricultural Research 6(9): 2026-2032.

4. Aldesuquy HS (1998) Effect of gibberellic acid, indol-3-acitic acid, abscisic acid and sea water on growth characteristics and chemical composition of wheat seedlings. Egypt J Physiol Sci 22: 451-466.

5. Yoshiba Y, Kiyosue T, Nakashima K, Yamaguchishinozaki K, Shinozaki K (1997) Regulation of levels of proline as an osmolyte in plants under water stress. Plant and Cell Physiol 38(10): 1095-1102.
6. Bettaieb I, Zakhama N, Wannes WA, Kchouk ME, Marzouk B (2009) Water deficit effects on Salvia officinalis fatty acids and essential oils composition. Scientia Horticulturae 120: 271-275.

7. Bowne JB, Erwin TA, Juttner J, Schnurbusch T, Langridge P, et al. (2012) Drought responses of leaf tissues from wheat cultivars of differing drought tolerance at the metabolite level. Molecular Plant 5(2): 418429.

8. Dornbos DL, Mullen RE (1992) Soybean seed protein and oil contents and fatty acid composition adjustments by drought and temperature. Journal of the American Oil Chemists Society 69(3): 228-231.

9. Specht JE, Chase K, Macrander M, Graef GL, Chung J, et al. (2001): Soybean response to water: A QTL analysis of drought tolerance. Crop Sci 41(2): 493-509.

10. Abou El-Yazied AA (2011) Foliar Application of glycine betaine and chelated calcium improves seed production and quality of common Bean (Phaseolus Vulgaris L.) under water stress conditions. Res J Agric and Biol Sci 7(4): 357-370.

11. Rahman MS, Miyake H, Takeoka Y (2002) Effects of exogenous glycinebetaine on growth and ultra-structure of salt-stressed rice seedlings (Oryza sativa L.). Plant Prod Sci 5(1): 33-44.

12. Aldesuquy HS, Abass MA, Abo- Hamed SA, Elhakem AH, Alsokari SS (2012) Glycine betaine and salicylic acid induced modification in productivity of two different cultivars of wheat grown under water stress. Journal of Stress Physiology \& Biochemistry 8(2): 69-86.

13. Aldesuquy HS (2013) Glycine betaine and salicylic acid induced modification in water relations and productivity of drought wheat plants. Journal of Stress Physiology and Biochemistry 10: 55-73.

14. Maghsoudia K, Arvinb MJ (2010) Salicylic acid and osmotic stress effects on seed germination and seedling growth of wheat (Triticum aestivum L.) cultivars. Plant Ecophysiol 2: 7-11.

15. Szepesi A, Gémes K, Orosz G, Petô A, Takács Z, et al. (2011) Interaction between salicylic acid and polyamines and their possible roles in tomato hardening processes. Acta Biologica Szegediensis 55(1): 165166.

16. Hussain M, Farooq M, Jabran K, Wahid A (2010) Foliar Application of Glycine betaine and Salicylic Acid Improves Growth, Yield and Water Productivity of Hybrid Sunflower Planted by Different Sowing Methods. J Agron and Crop Sci 196(2): 136-145.

17. Riazi A, Matsuda K, Arslan A (1985) Water stress induced changes in concentrations of proline and other solutes in growing regions of young barely leaves. J Exp Bot 36(172): 1716-1725.

18. Thayermanavan V, Sadasivam S (1984) Qual Plant Foods Hum Nutr 34: 253-257. In: Sadasivam S, Manickam A (Eds.), Quoted from Biochemical Methods. (2 ${ }^{\text {nd }}$ edn), New ag inter Limit Publ, New Delhi, India, pp.11-12.

19. Lowry OH, Rosebrough NJ, Farr AL (1951) Protein measurement with the Folin phenol reagent. J Biol Chem 193(1): 265-276.

20. Sempio C, Rsggi V (1966) Amino acids liberie e combinati in Piante di Fava (Vicia faba major) infettate con Uromyces fabae. Phytopopathol Z 55(2): 117-171.

21. Williams V, Twine S (1960) Flam photometer method for sodium, potassium and calcium. In: Peach K, Tracey MV (Eds.), Modern Methods of Plant Analysis. Springer- Verlag, Berlin, USA, pp. 3-5.

22. Hansen EM, Munns DN (1988) Effect of $\mathrm{CaSO}_{4}$ and $\mathrm{NaCl}$ on mineral content of Leucaena leucocephala. Plant and Soil 107(1): 101-105.

23. Barker J, Mapson LW (1964) Studies in the respiratory and carbohydrate metabolism of plant tissues. XV. The effect of certain enzymic poisons on respiration, sugar and ascorbic acid of detached leaves. J Exp Bot 15(44): 272-283. 
24. Humphries EC (1956) Mineral components and ash analysis. In: Pesch K, Tracey MV (Eds.), Modern Method of Plant Analysis. Springer -Verlag, Berlin, Germany.

25. Egeli DB, Guffy RD, Meckel LW, Leggett JE (1985) The effect of sourcesink alterations on soybean seed growth. Ann Bot 55(3): 395-399.

26. Sankar B, Jaleel CA, Manivannan P, Kishorekumar A, Somasundaram R, et al. (2007) Drought induced biochemical modifications and proline metabolism in Abelmoschus esculentus (L.) Moench. Acta Bot Croat 66(1): 43-56.

27. Larque-Saavedra A (1979) Stomatal closoure in response to acetylsalicylic acid treatment. Z Pflannzenphysiol 93: 371-375.

28. Taji T, Ohsumi C, Iuchi S, Seki M, Kasuga M, et al. (2002) Important roles of drought and cold inducible genes for galactinol synthase in stress tolerance in Arabidopsis thaliana. Plant J 29(4): 417-426.

29. El-Tayeb MA (2005) Response of barley grains to the interactive effect of salinity and salicylic acid. Plant Growth Regul 45(3): 215-224.

30. Greenway HR, Munns R (1980) Mechanism of salt tolerance in nonhalophytes. Annu Rev Plant Physiol 31: 149-190.

31. Caputo C, Barneix AJ (1997) Amino acids export to the phloem in relation to $\mathrm{N}$ supply in wheat (Triticum aestivum L.) plants. Physiol Plant 101(4): 853-860.

32. Riens B, Lohaus G, Heineke D, Heldt HW (1991) Amino acid and sucrose content determined in the cytosolic, chloroplastic, and vacuolar compartments and in the phloem sap of spinach leaves. Plant Physiol 97(1): 227-233.

33. Lohaus G, Burba M, Heldt HW (1994) Comparison of the contents of sucrose and amino acids in the leaves, phloem sap and taproots of high and low sugar producing hybrids of sugar beet (Beta vulagaris L.). J Exp Bot 45(8): 1097-101.

34. Chandrashekar KR, Sandhyarani S (1996) Salinity induced chemical changes in Crotalaria striata Dc Plants. Indian J Plant Physiol 1(1): 44 48.

35. El-Tayeb MA, El-Enany AE, Ahmed NL (2006) Salicylic acid induced adaptive response to copper stress in sunflower (Helianthus annuus L.). Plant Growth Regul 50(2/3): 191-199.

36. Hussein MM, Balbaa LK, Gaballah MS (2007) Salicylic acid and salinity effects on growth of maize plants. Res J Agric and Biol Sci 3(4): 321328.

37. Mikami K, Murata N (2003) Membrane fluidity and the perception of environmental signals in cyanobacteria and plants. Prog Lipid Res 42(6): 527-543.

38. Taarit MB, Msaada K, Hosni K, Marzouk B (2010) Changes in fatty acid and essential oil composition of sage Salvia officinalis (L.) leaves under $\mathrm{NaCl}$ stress. Food Chemistry 119: 951-956.

39. Xu X, Beardall J (1997) Effect of salinity on fatty acid composition of a green microalga from an antarctic hypersaline lake. Phytochemistry 45: 655-658.
40. Nam KH, Kim DY, Shin HJ, Nam KJ, An JH, et al. (2014) Drought stressinduced compositional changes in tolerant transgenic rice and its wild type. Food Chemistry 153: 145-150.

41. Javed S, Ashraf MY, Mahmood S, Bukhari SA, Meraj M (2013) Comparative Evaluation of Biochemical Changes in Different Safflower Varieties (Carthamus tinctorius L.) under Water Deficit. J Food Process Technol 4: 270 .

42. Lehninger AL (1975) Biochemistry, the molecular basis of cell structure and function: Albert L. Lehninger. ( $2^{\text {nd }}$ edn), 1975. Worth Publishers, Inc., New York, USA, pp. 1104.

43. Francois LE, Kleiman R (1990) Salinity effects on vegetative growth, seed yield and fatty acid composition of crambe. Agricultural Journal 82(6): 1110-1114.

44. Kerkeb L, Donaire JP, Rodriguez-Rosales MP (2001) Plasma membrane $\mathrm{H}+$-ATPase activity is involved in adaptation of tomato to $\mathrm{NaCl}$. Physiologiae Plantarum 111(4): 483-490.

45. Mansour MMF, Salama KHA (2004) Cellular basis of salt tolerance in plants Environmental and Expermintal Botany 52: 113-122.

46. El-Beltagi HS, Salama ZA, El-Hariri DM (2007) Evaluation of fatty acids, proline and the content of some secondary metabolites in seeds of different flax cultivars (Linum usitatissimmum). Plant Physiology 33(3-4): 187-202.

47. Stefanoudaki E, Williams M, Chartzoulakis K, Harwood J (2009) Olive oil qualitative parameters after orchard irrigation with saline water. Journal of Agricultural and Food Chemistry 57(4): 1421-1425.

48. Azachi M, Sadka A, Fisher M, Goldshlag P, Gokhman I, et al. (2002) Salt Induction of fatty Acid elongase and membrane lipid Modifications in the extreme halotolerant Alga Dunaliella salina. Plant Physiology 129(3): 1320-1329.

49. Allakhverdiev SI, Sakamoto A, Nishiyama Y, Inaba M, Murata N (2000) Ionic and osmotic effects of nacl-induced inactivation of photosystems I and II in synechococcus sp. Plant Physiology 123(3): 1047-1056.

50. Allakhverdiev SI, Kinoshita M, Inaba M, Suzuki I, Murata N (2001) Unsaturated fatty acids in membrane lipids protect the photosynthetic machinery against salt-induced damage in Synechococcus. Plant Physiology 125(4): 1842-1853.

51. Baldini M, Givanardi R, Vanozzi GP (2000) Effect of different water availability on fatty acid composition of the oil in standard and high oleic sunflower hybrids. International Sunflower Conference, (15) Proceedings, Tome I, Paris, France.

52. Mäetak P, Käinen J, Somersalo S (2000) Effect of glycine betaine on chloroplast ultrastructure, chlorophyll and protein content, and RuBPCO activities in tomato grown under drought or salinity. Biol Plant 43(3): 471-475.

53. Aldesuquy HS, Abass MA, Abo-Hamed SA, Elhakem AH (2013) Effect of glycine betaine and salicylic acid on growth and productivity of droughted wheat cultivars: Image analysis for measuring the anatomical features in flag leaf and peduncle of the main shoot. Journal of Stress Physiology \& Biochemistry 9(2): 35-63. 
This work is licensed under Creative Commons Attribution 4.0 License

DOI: 10.19080/ARTOAJ.2017.07.555724
Your next submission with Juniper Publishers will reach you the below assets

- Quality Editorial service

- Swift Peer Review

- Reprints availability

- E-prints Service

- Manuscript Podcast for convenient understanding

- Global attainment for your research

- Manuscript accessibility in different formats

( Pdf, E-pub, Full Text, Audio)

- Unceasing customer service

Track the below URL for one-step submission

https://juniperpublishers.com/online-submission.php 